\title{
lodine excretion has decreased in Denmark between 2004 and 2010 - the importance of iodine content in milk
}

\author{
Lone B. Rasmussen $^{1 *}$, Allan Carlé ${ }^{2}$, Torben Jørgensen ${ }^{3,4}$, Pia Knuthsen ${ }^{5}$, Anne Krejbjerg ${ }^{2}$, Hans Perrild ${ }^{6}$, \\ Lena Bjergved $^{3}$, Jens J. Sloth ${ }^{5}$, Peter Laurberg ${ }^{2}$ and Lars Ovesen ${ }^{7}$ \\ ${ }^{1}$ Division of Nutrition, National Food Institute, Technical University of Denmark, Mørkhøj Bygade 19, 2860 Søborg, \\ Denmark \\ ${ }^{2}$ Department of Endocrinology, Aalborg University Hospital and Department of Clinical Medicine, Aalborg University, \\ Aalborg, Denmark \\ ${ }^{3}$ Research Centre for Prevention and Health, The Capital Region of Denmark, Glostrup, Denmark \\ ${ }^{4}$ Faculty of Health Science, University of Copenhagen, Denmark and Faculty of Medicine, University of Aalborg, \\ Aalborg, Denmark \\ ${ }^{5}$ Division of Food Chemistry, National Food Institute, Technical University of Denmark, Søborg, Denmark \\ ${ }^{6}$ Department of Endocrinology and Gastroenterology, Bispebjerg University Hospital, Copenhagen, Denmark \\ ${ }^{7}$ Department of Gastroenterology, Slagelse Hospital, Slagelse, Denmark
}

(Submitted 25 April 2014 - Final revision received 8 September 2014 - Accepted 9 September 2014 - First published online 30 October 2014)

\section{Abstract}

Fortification with the essential trace element iodine is widespread worldwide. In the present study, results on iodine excretion and intake of iodine-rich foods from a cross-sectional study carried out in 2004-5, 4 to 5 years after the implementation of mandatory iodine fortification, were compared with data in a study carried out in 2008-10. The 2008-10 study was a follow-up of a cross-sectional study carried out before iodine fortification was implemented. Participants in the cross-sectional studies were randomly selected. Both studies were carried out in the cities of Aalborg and Copenhagen in Denmark. The median urinary iodine concentration decreased in women from $97 \mu \mathrm{g} / \mathrm{l}$ ( $n$ 2862) to $78 \mu \mathrm{g} / 1$ ( $n$ 2041) $(P<0 \cdot 001)$. The decrease persisted after adjustment for age, city and education, and if expressed as estimated $24 \mathrm{~h}$ iodine excretion. The prevalence of users of iodine containing dietary supplements increased from $29 \cdot 4$ to $37 \cdot 3 \%(P<0 \cdot 001)$. The total fluid intake increased in women $(P<0 \cdot 001)$, but the intake of other iodine-rich foods did not change. The median urinary iodine concentration did not change in men $(114 \mu \mathrm{g} / \mathrm{l}(n$ 708) and $107 \mu \mathrm{g} / \mathrm{l}(n$ 424), respectively), while the total fluid intake decreased $(P=0 \cdot 001)$. Iodine content was measured in milk sampled in 2000-1 and in 2013. The iodine content was lower in 2013 (12 (sD 3) $\mu \mathrm{g} / 100 \mathrm{~g}) \mathrm{compared}$ with that in 2000-1 (16 (SD 6) $\mu \mathrm{g} / 100 \mathrm{~g})(P<0 \cdot 001)$. In conclusion, iodine excretion in women has decreased below the recommended level. The reason might probably, at least partly, be a decreased content of iodine in milk.

Key words: Fortification: Nutrient intake: Iodine content in milk

Iodine is an essential micronutrient and lack of iodine in the diet may result in a spectrum of diseases known as iodinedeficiency diseases. Iodine-deficiency diseases are easy and cheap to prevent by the addition of a small amount of iodine to the salt that people consume daily. Salt iodisation is widespread, and iodine deficiency has been eliminated or decreased in many countries ${ }^{(1)}$. However, iodine deficiency has also reappeared in some countries that have been thought to have sufficient iodine intake $\mathrm{e}^{(2-4)}$. Monitoring of the effect of iodine fortification is essential to ensure that it is functioning as planned and to provide the information needed to take corrective action if necessary ${ }^{(5)}$.
Before 1998, mild-to-moderate iodine deficiency existed in Denmark $^{(6)}$. A voluntary iodine fortification programme was introduced in Denmark in 1998, and in 2000, iodine fortification was changed to a mandatory fortification of household salt and bread salt at a level of $13 \mu \mathrm{g} / \mathrm{g}$ salt ${ }^{(7)}$. Before iodine fortification was introduced, and again in 2004-5, 4 to 5 years after the introduction of mandatory fortification, cross-sectional studies were carried out. The results of the cross-sectional study carried out in 2004-5 showed an increase in iodine urinary excretion to just above the recommended $100 \mu \mathrm{g} / \mathrm{l}^{(6)}$. In 2008-10, a follow-up study including the participants from the first cross-sectional study (1997-8) was carried out.

*Corresponding author: L. B. Rasmussen, fax +45 35887119, email lbra@food.dtu.dk 
Milk has been found to be the most important dietary source of iodine in Denmark ${ }^{(6)}$. Likewise, milk is an important iodine source in other countries ${ }^{(8-10)}$. Therefore, possible changes in iodine content in milk can have a large effect on iodine intake, and should be assessed as part of a monitoring programme.

Results from the studies conducted in 2004-5 and in 2008-10, 4 to 5 years and about 9 years after the implementation of mandatory iodine fortification, respectively, have been published separately before ${ }^{(11-13)}$. In the present study, the results of the two studies are compared with regard to urinary iodine excretion and intake of iodine-rich foods. Thus, the aim of the present study was to describe possible differences in urinary iodine excretion from 2004-5 to 2008-10. Furthermore, iodine content in milk sampled in 2000-1 (not previously published) and in 2013 is presented, and possible reasons for the change in urinary iodine excretion are explored.

\section{Methods}

In the present study, results of urinary iodine excretion and intake of iodine-rich foods from two studies, both part of the Danish Investigation of Iodine Intake and Thyroid Diseases (DanThyr), were compared; a study carried out in 2004-5 and another study carried out in 2008-10. The study conducted in 2004-5 was a cross-sectional study and the study conducted in 2008-10 was a follow-up of a cross-sectional study carried out in 1997-8, before iodine fortification was implemented ${ }^{(11)}$.

The studies took place at two centres located in the cities of Copenhagen (situated in the eastern part of Denmark) and Aalborg (situated in the western part of Denmark). The two cities represented areas with mild and moderate iodine deficiency, respectively, before iodine fortification; the difference in iodine intake between the cities was mainly due to differences in iodine content in drinking water ${ }^{(14)}$. For the cross-sectional study (2004-5), a random sample was drawn from the Civil Registration System of all inhabitants in the two cities comprising the following groups: women aged 18-22, 25-30, 40-45 and 60-65 years, and men aged 60-65 years. These groups were chosen to represent women before the usual childbearing age, in the childbearing age and after the childbearing age, both pre-menopausal and postmenopausal. Primarily women were investigated as the occurrence of thyroid abnormalities is higher among women than among men. In total, 7658 subjects were invited, of which 3570 (46.6\%) participated in the 2004-5 cross-sectional study. For the second study (2008-10), participants from a cross-sectional study carried out in 1997-8 were invited. In the 1997-8 study, 9274 subjects were invited from the Civil Registration System in the same way and in the same age groups as described above, of which $4649(50 \cdot 1 \%)$ participated. Of the 4649 participants, seventy-two had emigrated and 403 had died, leaving 4174 subjects to be invited for the follow-up study. From this sample, 2465 subjects $(59 \cdot 1 \%)$ participated. The sample size for the baseline study in 1997-8 was determined to be able to identify a difference in thyroid volume of $3 \mathrm{ml}$ and a difference in iodine concentration in the urine of $10 \mu \mathrm{g} / \mathrm{d}$ between the various age groups, with $\alpha=0.05$ and $\beta=20 \%$. For the study in $2004-5$, the sample size was determined to be able to detect a difference in thyroid volume of $1 \mathrm{ml}$ for the age group 18-30 years, $2 \mathrm{ml}$ for the age group $40-45$ years and $3-4 \mathrm{ml}$ for the age group 60-65 years, and a difference in iodine concentration in the urine of at least $10 \mu \mathrm{g} / \mathrm{d}$ for each age group when compared with the study in 1997-8, with $\alpha=0.05$ and $\beta=20 \%$.

The two studies took place from 28 April 2004 to 14 July 2005 and from 22 February 2008 to 11 February 2010, respectively. All information gathered and procedures performed were standardised in both cities and were similar in both studies. The present study was conducted according to the guidelines laid down in the Declaration of Helsinki, and all procedures involving human subjects/patients were approved by the Danish Ethics Committee (no. 2-16-4-0001-97 and VN 96/208mch and N-VN-19960208MCH, the Northern Danish Region Committee). All participants gave written informed consent.

The studies have been described in more detail previously $^{(11-13)}$.

\section{Dietary supplements and FFQ}

Participants were invited to one of the two centres, and asked to bring with them all dietary supplements taken and daily intake of iodine from supplements was recorded.

A FFQ covering iodine-rich foods was given to all participants in both studies during their visit. The FFQ was semi-quantitative and was similar in both studies, and included a list of sixty-three iodine-rich food items. The FFQ has been evaluated and described in more detail elsewhere $^{(15)}$. In the present study, the FFQ was only used to explore changes in the intake of iodine-rich foods. The FFQ gave useful data for 3522 participants in the first study and 2424 participants in the second study.

\section{Collection of urine samples}

All participants were asked to give a single, random spot urine sample when they visited the centre. The visits took place between 08.00 and 17.30 hours.

\section{Collection of milk samples}

Milk was sampled in 2013, and the results on iodine content were compared with previously unpublished results on iodine content found in milk sampled and analysed in 2000-1. Denmark has only few dairies, which produce milk, and one of the dairies (Arla) has a market share of approximately $85 \%$.

2000-1 sampling. Milk samples were taken every month throughout a year at the three dairies that delivered virtually all milk to the Danish market and from the two largest organic dairies. Thus, the samples were representative of the Danish consumption. In total, thirty-six samples of non-organic and twenty-four samples of organic semi-skimmed milk (fat content approximately $1.5 \%$ ), and further thirty-six samples of non-organic whole milk (fat content approximately $3.5 \%$ ) were taken. Samples were taken throughout a whole year, 
from September 2000, thus taking the expected seasonal variation into account.

2013 collection. Milk was sampled from mainly the same dairies as in the 2000-1 sampling. In total, forty-seven samples of organic milk (whole milk and skimmed milk) and forty-two samples of non-organic milk (whole milk and skimmed milk) were collected. Milk was collected in April and in July/August 2013; in April, all cows are still kept in the stable, and therefore samples taken at that time represented winter milk.

Milk originated from mainly the same dairies in both collections; the non-organic milk from Arla's three dairies, two in Jutland and one in Zealand, and the organic milk from Arla's dairy in Zealand, from Naturmælk (in Jutland) and from Thiese (in Jutland). A few of the organic samples in the 2013 collection came from the dairy Øllingegård situated on Zealand. Furthermore, a few samples, which originated from Germany ( $n$ 4), were also collected in 2013, as German milk is now found in some supermarkets.

\section{lodine analyses}

For the analyses of iodine content in urine samples from both population studies and in consumer milk collected in 2013, samples were first treated to remove organic materials as described in detail by Wilson \& van $\mathrm{Zyl}^{(16)}$. In brief, $1.25 \mathrm{ml}$ of sample and $1.00 \mathrm{ml}$ of $2 \mathrm{M}-\mathrm{KOH}$ and $0.5 \% \mathrm{KClO}_{3}$ were added to iodine-free thermo-resistant $16 \times 100 \mathrm{~mm}$ Pyrex glasses, mixed and incubated in a furnace oven at $90-95^{\circ} \mathrm{C}$ until dryness $(24 \mathrm{~h})$. The oven temperature was then increased to $450^{\circ} \mathrm{C}$ for $60 \mathrm{~min}$ followed by $620^{\circ} \mathrm{C}$ for $180 \mathrm{~min}$. After alkaline ashing, the remnants were resuspended in $1.25 \mathrm{ml}$ distilled water and incubated for $5 \mathrm{~min}$ in a laboratory shaker, and subsequently centrifuged at $3000 \mathrm{rpm}$ for $15 \mathrm{~min}$. Inorganic iodine was measured in the supernatant by the Sandell-Kolthoff method, which is based on the catalytic effect of iodide on the reaction between $\mathrm{Ce}^{4+}$ and $\mathrm{As}^{3+}$, as described previously ${ }^{(17)}$.

Recovery of iodine during alkaline ashing was about $95 \%$ in previous studies ${ }^{(17)}$, and it has been retested to be at this level for both urine and milk samples. In brief, fifteen urine samples with a median iodine content of 35 (range 15-80) $\mu \mathrm{g} / \mathrm{l}$ were spiked with the analytical-grade KI solution used as the standard corresponding to an increase in iodine concentration of $32 \mu \mathrm{g} / \mathrm{l}$. Recovery of iodine was 95.9 (sem 2.4 ) \%. Similarly, the mean recovery of iodine added to milk was 94 (range 83-102) \%, when measured on eight samples with a mean basic iodine concentration of 103 (range 91-116) $\mu \mathrm{g} / \mathrm{l}$ and spiked with KI to contain an extra $100 \mu \mathrm{g} / \mathrm{l}$. The final values were not corrected for percentage recovery.

The correctness of the level of iodine measured in inorganic supernatants was tested by participating in the Center for Disease Control (CDC, Atlanta, USA) Equip quality programme every 4 month. The received blind urine samples were treated as described above, and at the time of analyses in the present study, quality controls at three levels were measured to contain a mean of $59 \cdot 2 \mu \mathrm{g} / 1$ (triplicate measurement, CV $1.7 \%$ ), $105.3 \mu \mathrm{g} / \mathrm{l}$ (CV 1.7\%) and $175.5 \mu \mathrm{g} / \mathrm{l}$ (CV 1.3\%), whereas average results from nine different measurements by the CDC ICP-dynamic reaction cell-MS reference method over at least three different days were 64.3, 110.9 and $184.3 \mu \mathrm{g} / \mathrm{l}$, respectively. Serial dilutions of urine and milk samples gave curves parallel to the standard curve. Analytical precision was estimated from triplicate ashing and analysis of a urine sample containing $93.9 \mu \mathrm{g} / \mathrm{l}$ in eighteen assays, and the intra- and inter-assay $\mathrm{CV}$ for single determinations were $2 \cdot 1$ and $2 \cdot 7 \%$, respectively. For the Sandell-Kolthoff analyses, the lowest standard above the zero blank contained $10 \mu \mathrm{g}$ iodine/1. With this set-up, the limit of detection varied between 2 and $3 \mu \mathrm{g} / \mathrm{l}$. The standard was prepared from KI for analysis (Merck).

Iodine concentrations in urine samples from the 2004-5 study and the 2008-10 study were measured in different runs. When thirty samples from the first study were measured again with regard to urine samples from the 2008-10 study, no significant differences $(P>0.05)$ from the first measurement were observed.

Analyses of milk sampled in 2000-1 were performed by inductively coupled plasma MS (ELAN 6100DRC; Sciex/ Perkin Elmer) following dilution of the milk samples $(1+19)$ with $0 \cdot 5 \mathrm{~m}$ aqueous $\mathrm{NH}_{3}$ (Merck) ${ }^{(18)}$. Quantification was done using the ${ }^{127} \mathrm{I}$ isotope by external calibration with internal standardisation using ${ }^{125} \mathrm{Te}$. The accuracy of the analysis was estimated by the analysis of a certified reference material BCR63R Skim milk powder (Institute of Reference Materials and Measurements). The results (812 (SD 62) $\mu \mathrm{g} / \mathrm{kg}$ ( $n$ 11)) obtained are in good agreement with the certified target value at $810(\mathrm{SD} 50) \mu \mathrm{g} / \mathrm{kg}$. Precision of the analysis was evaluated as satisfactory by duplicate analysis of selected samples ( $n$ 18) at $\mathrm{CV}=8.5 \%$. The limit of detection was estimated at 0.4 (SD 3$) \mu \mathrm{g} / \mathrm{kg}$ from the analysis of the blank samples.

Overall, five milk samples from 2013 were sent for analysis of iodine with inductively coupled plasma MS in the same laboratory as the samples from 2000-1 to compare the analytical methods. The mean value for the five samples analysed with inductively coupled plasma MS was $9 \cdot 1 \mu \mathrm{g} / 100 \mathrm{~g}$ and for the Ce-As method was $8.2 \mu \mathrm{g} / 100 \mathrm{~g}(P>0.05)$.

\section{Creatinine analyses}

Urinary creatinine concentration was determined using Vitros creatinine slides and Vitros Chemistry Products Calibrator Kits on a Vitros 250 chemistry system (Ortho-Clinical Diagnostic System, Inc.). Intra- and inter-assay CV were below 5\%. Equipment was calibrated according to the manufacturer's instructions, and external standards included standards from the Danish Institute for External Quality Assurance for Laboratories in Health Care (DEKS). Dilution and recovery tests were satisfactory. In all assay runs, samples from the different subgroups of the study population were included in random order.

\section{Expressions of iodine excretion}

Urinary iodine excretion was expressed in two ways: as a concentration and as an estimated $24 \mathrm{~h}$ urinary iodine excretion. 
To calculate the estimated $24 \mathrm{~h}$ urinary iodine excretion, the iodine:creatinine ratio was multiplied by the calculated $24 \mathrm{~h}$ creatinine excretion. The calculation of the $24 \mathrm{~h}$ creatinine excretion was done by using a formula including weight, height and age for each sex, respectively ${ }^{(19)}$. The formula was developed from data collected in Danish studies. Iodine concentration in the urine was available for 3554 participants in the 2004-5 study and for 2453 in the 2008-10 study.

\section{Statistical analysis}

Data were analysed with the Statistical Package for the Social Sciences statistical software (version 20.0; IBM SPSS, Inc.). Results for urine excretion are expressed in three different ways: as medians with 25 th and 75 th percentiles; as geometric means and standard deviations; as adjusted geometric means with $95 \%$ CI.

Adjusted geometric mean values were calculated using mixed models with age at examination as the continuous variable, educational level (no further education, semi-skilled, short theoretical ( $<3$ years) and theoretical ( $\geq 3$ years)) and city as independent variables and logarithmically transformed iodine excretion as the dependent variable.

When comparing the two studies with regard to urinary iodine excretion or iodine-rich foods, the Mann-Whitney $U$ test was used for median values and Student's $t$ test for mean values. A $\chi^{2}$ test was used when comparing users of iodine-containing supplements in the two studies.

The relationships between urinary iodine excretion and the age group (18-22, 25-30, 40-45 and 60-65 years) were explored using the Kruskal-Wallis $H$ test.

Iodine content in milk was normally distributed, and is expressed as means and standard deviations. Comparisons between iodine content in different milk samples were made by Student's $t$ test.

\section{Results}

Urinary iodine excretion given as a concentration and as estimated $24 \mathrm{~h}$ iodine excretion in men and women, respectively, after approximately 4 and 9 years of mandatory iodine fortification is shown in Table 1. Both expressions of iodine excretion were significantly lower in women 9 years after (in 2008-10) than 4 years after (in 2004-5) the introduction of mandatory fortification, and also after adjustment for age, education and city. The percentage of participants who used dietary supplements with iodine was higher after 9 years of fortification than after 4 years of fortification for women, but did not change for men (Table 1 ).

Estimated $24 \mathrm{~h}$ iodine excretion in women increased significantly with age both in $2004-5(P<0.001)$ and in 2008-10 ( $P=0.002)$. Likewise, iodine concentration in the urine increased with age in both studies $(P<0 \cdot 001$; results not shown).

Geometric mean estimated $24 \mathrm{~h}$ iodine excretion was higher during winter (October to April) than during summer (May to September) in 2004-5 (160 (95\% CI 155, 166) $\mu \mathrm{g} / 1 v .151$ (95\% CI 145,156$) \mu \mathrm{g} / 1, P=0 \cdot 004)$, whereas no seasonal difference was found in 2008-10 (144 (95\% CI 138 , 150) $\mu \mathrm{g} / \mathrm{l} v$. $142(95 \%$ CI 136,149$) \mu \mathrm{g} / \mathrm{l}, \quad P=0.744)$ when adjusted for city, age, sex and education.

Urinary iodine excretion in women for each city is shown in Table 2. Urinary iodine excretion decreased significantly in both cities from 2004-5 to 2008-10 both when expressed as a concentration and as estimated $24 \mathrm{~h}$ excretion.

Total calculated water intake (including water, coffee, tea, fruit juice and soft drinks) and calculated total fluid intake (including both water and milk) increased significantly in women, but decreased in men (Table 3). Total milk intake (including all kinds of milk and yogurt) and the intake of other iodine-rich foods (fish, bread and eggs) did not change significantly for either sex between the two studies.

Fewer participants reported of buying mainly organic milk in the 2004-5 study (38\%) than in the 2008-10 study (50\%) $(P<0 \cdot 001)$. Furthermore, fewer participants stated that they always or often made bread themselves in the 2004-5 study (24\%) than in the 2008-10 study (31\%) $(P<0.001)$, but the percentage of participants who always or often bought bread at a bakery store did not change (36 and 38\% in 2004-5 and 2008-10, respectively, $P=0 \cdot 12$ ).

In non-organic milk sampled in 2000-1, iodine content was significantly higher than in milk sampled in 2013, but iodine content in organic milk was highest in milk sampled in 2013 (Table 4). Iodine content was significantly higher in non-organic milk than in organic milk $(P<0 \cdot 031)$. The mean iodine content in milk sampled in 2000-1 was 16 (SD 6) $\mu \mathrm{g} / 100 \mathrm{~g}$ and in 2013 , the mean iodine content weighted for the same distribution of organic/non-organic milk as in 2000-1 was 12 (SD 3) $\mu \mathrm{g} / 100 \mathrm{~g}(P<0 \cdot 001)$. Iodine content in milk from dairies on Zealand was higher than that from dairies in Jutland $(P=0 \cdot 001)$ in $2000-1$, whereas in 2013 , no difference was found in iodine content in milk from dairies in Jutland compared with that in dairies on Zealand. No difference in iodine content between semi-skimmed milk (21 (SD 4) $\mu \mathrm{g} / 100 \mathrm{~g}$ ) and whole milk (21 (SD 4) $\mu \mathrm{g} / 100 \mathrm{~g}$ ) was found in the 2000-1 study $(P=0 \cdot 740)$. Likewise, iodine content in skimmed milk did not differ from that in whole milk 13 (SD 3) and 13 (SD 2) $\mu \mathrm{g} / 100 \mathrm{~g}$, respectively $(P=0.43)$ in 2013. The mean iodine content in milk that originated from Germany was 14 (SD 2) $\mu \mathrm{g} / 100 \mathrm{~g}$ ( $n$ 4) in 2013 (none was sampled in the 2000-1 study).

\section{Discussion}

Iodine concentration in the urine showed a decrease in Danish women 9 years after mandatory iodine fortification compared with iodine concentration after 4 years, despite a higher intake of iodine-containing supplements, and the excretion was low compared with the recommended level ${ }^{(5)}$. The decrease in urinary iodine concentration could not be explained by a change in urinary dilution, as urinary iodine excretion also decreased when expressed as estimated $24 \mathrm{~h}$ urinary iodine excretion. Urinary iodine concentration did not change in men. However, only men aged 60-65 years in 2004-5 participated, and a lower urinary volume in 2008-10 could probably have counteracted a possible decrease in 
Table 1. Urinary iodine excretion and users of iodine supplements in $2004-5$ and in $2008-10,4$ and 9 years after the introduction of mandatory iodine fortification, respectively

(Median values and 25-75 percentiles; geometric mean values and standard deviations; adjusted geometric mean values and $95 \%$ confidence intervals)

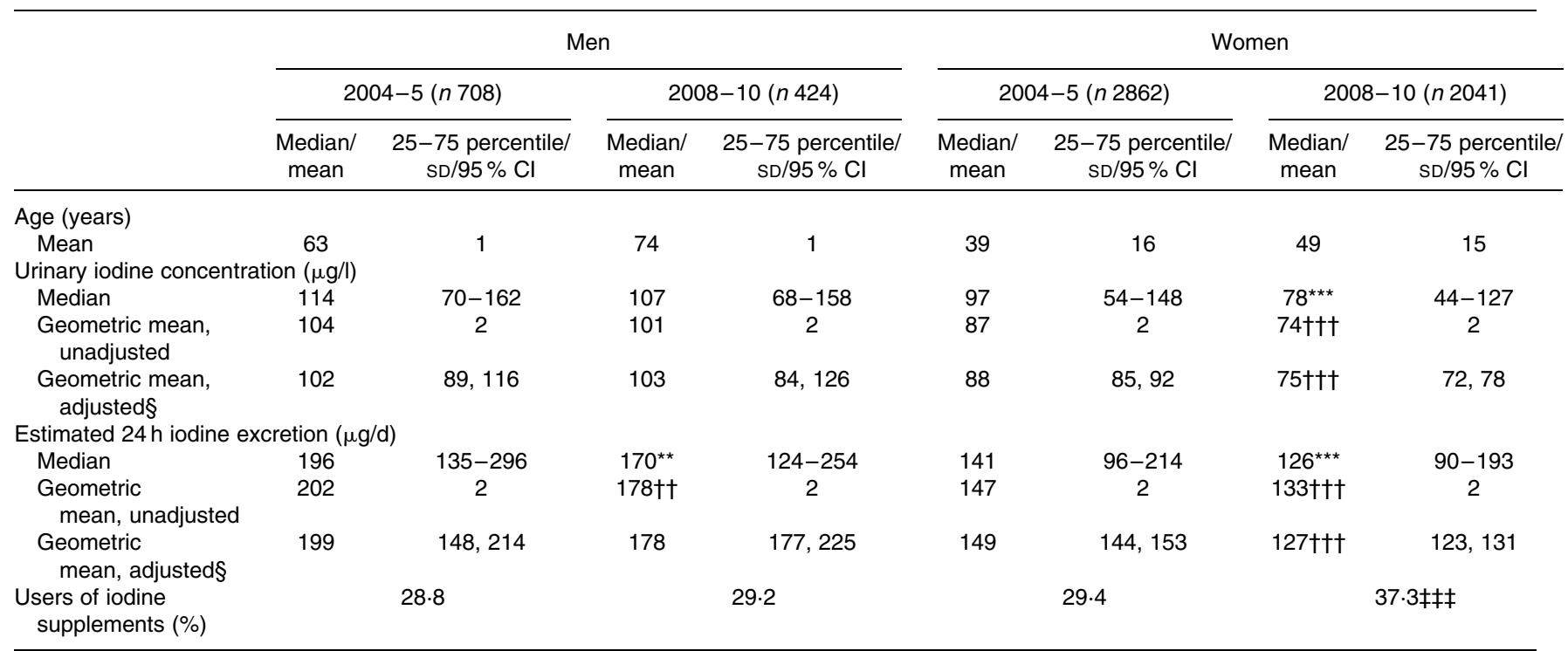

Median value was significantly different from that after 4 years of fortification $(2004-5):{ }^{\star \star} P=0.001,{ }^{\star \star \star} P<0.001$ (Mann-Whitney test).

Mean value was significantly different from that after 4 years of fortification (2004-5): $\dagger \dagger P=0.001, \dagger \dagger \dagger P<0.001$ ( $t$ test).

$\ddagger \ddagger \ddagger$ Value was significantly different from that after 4 years of fortification $(2004-5)\left(P<0.001 ; \chi^{2}\right.$ test $)$.

$\S$ Adjusted for age, education and city.

iodine excretion when expressed as a concentration in this age group as the estimated $24 \mathrm{~h}$ iodine excretion decreased.

The $24 \mathrm{~h}$ iodine excretion can be compared with the recommended intake of $150 \mu \mathrm{g} / \mathrm{d}^{(20)}$ with extraction of $10 \mu \mathrm{g} / \mathrm{d}$ excreted in the faeces; that is, the optimal daily urinary iodine excretion is approximately above $140 \mu \mathrm{g} / \mathrm{d}$. According to this measure, the estimated $24 \mathrm{~h}$ iodine excretion was below the optimal level in women. The median urinary iodine concentration in women was below $100 \mu \mathrm{g} / \mathrm{l}$, which is the level recommended by the WHO. It has been questioned whether this level is too high in adults, and a level of $60-70 \mu \mathrm{g} / 1$ has been suggested ${ }^{(21)}$. However, before iodine fortification was introduced in Denmark the median urinary iodine concentration was $68 \mu \mathrm{g} / 1$ in Eastern Denmark when $15 \%$ had thyroid enlargement, and the occurrence of multinodular toxic goitre was $11.5 \%{ }^{(11)}$. Thus, iodine intake at that level does not seem to be optimal.
Iodine deficiency, defined as a median iodine concentration in the urine below $100 \mu \mathrm{g} / \mathrm{l}$ for a sufficiently large group, still exists in both children and adults in some European and other Western countries ${ }^{(1)}$. In addition, low iodine intake ${ }^{(22)}$ or low urinary iodine excretion ${ }^{(23-25)}$ have been found in pregnant women in a number of European countries. Moreover, iodine deficiency has re-emerged in some countries such as Australia $^{(2)}$, Germany ${ }^{(4)}$ and the $\mathrm{UK}^{(3)}$. In Australia, decreased iodine intake is explained by chlorine-containing sanitisers replacing iodine-containing sanitisers in the dairy industry, with a lower iodine content in milk as a result, and by decreased consumption of iodised $\operatorname{salt}^{(2)}$. A possible reason for the negative trend in Germany is decreased use of iodised salt in industrial products ${ }^{(4)}$ and in the UK, the reason was proposed to be a decreased intake of $\operatorname{milk}^{(3)}$. In Iceland, which traditionally has a high intake of fish and thus a high iodine intake, intake of iodine has decreased during recent

Table 2. Urinary iodine excretion expressed as a concentration and as estimated $24 \mathrm{~h}$ iodine excretion in $2004-5$ and $2008-10$ (4 and 9 years after the introduction of mandatory iodine fortification, respectively) in the two investigated cities for women

(Geometric meanst and $95 \%$ confidence intervals)

\begin{tabular}{|c|c|c|c|c|c|c|}
\hline & \multicolumn{3}{|c|}{$2004-5$} & \multicolumn{3}{|c|}{$2008-10$} \\
\hline & Geometric mean & $95 \% \mathrm{Cl}$ & $n$ & Geometric mean & $95 \% \mathrm{Cl}$ & $n$ \\
\hline Iodine concentration, Copenhagen ( $\mu \mathrm{g} / \mathrm{l})$ & 94 & 89,99 & 1780 & $76^{\star \star \star}$ & 72,80 & 1229 \\
\hline lodine concentration, Aalborg $(\mu \mathrm{g} / \mathrm{l})$ & 82 & 78,87 & 1774 & $74^{\star \star \star}$ & 70,78 & 1223 \\
\hline Estimated iodine excretion, Copenhagen $(\mu \mathrm{g} / 24 \mathrm{~h})$ & 163 & 156,170 & 1775 & $136^{\star \star *}$ & 130,142 & 1199 \\
\hline Estimated iodine excretion, Aalborg ( $\mu \mathrm{g} / 24 \mathrm{~h})$ & 135 & 130,141 & 1764 & $119^{\star \star \star}$ & 114,125 & 1218 \\
\hline
\end{tabular}

${ }^{\star * \star}$ Mean value was significantly different from that after 4 years of fortification $(2004-5)(P<0.001)$

$\dagger$ Adjusted for age and education. 
Table 3. Intake of selected foods in 2004-5 and 2008-10, 4 and 9 years after the introduction of mandatory iodine fortification, respectively (Median values and $25-75$ percentiles)

\begin{tabular}{|c|c|c|c|c|c|c|c|c|}
\hline & \multicolumn{4}{|c|}{ Men } & \multicolumn{4}{|c|}{ Women } \\
\hline & \multicolumn{2}{|c|}{$2004-5$} & \multicolumn{2}{|c|}{$2008-10$} & \multicolumn{2}{|c|}{$2004-5$} & \multicolumn{2}{|c|}{$2008-10$} \\
\hline & Median & $\begin{array}{c}25-75 \\
\text { percentile }\end{array}$ & Median & $\begin{array}{c}25-75 \\
\text { percentile }\end{array}$ & Median & $\begin{array}{c}25-75 \\
\text { percentile }\end{array}$ & Median & $\begin{array}{c}25-75 \\
\text { percentile }\end{array}$ \\
\hline Water intake (glasses/d) $†$ & $7 \cdot 3$ & $5 \cdot 3-9 \cdot 6$ & $6 \cdot 8^{*}$ & $4 \cdot 7-8 \cdot 7$ & $8 \cdot 1$ & $6 \cdot 0-10 \cdot 4$ & $8 \cdot 9^{\star \star \star}$ & $6 \cdot 7-11 \cdot 1$ \\
\hline Total milk intake (glasses/d)‡ & 1.5 & $0.4-2 \cdot 1$ & 1.5 & $0.4-2.0$ & 1.6 & $0.7-2 \cdot 3$ & 1.6 & $0.6-2.2$ \\
\hline Intake of total fluid (glasses/d)§ & $8 \cdot 6$ & $6 \cdot 3-10 \cdot 9$ & $7 \cdot 7^{\star \star}$ & $6 \cdot 1-10 \cdot 1$ & $9 \cdot 6$ & $7 \cdot 3-11 \cdot 9$ & $10 \cdot 1^{\star \star \star}$ & $7 \cdot 9-12 \cdot 3$ \\
\hline Fish intake $(\mathrm{g} / \mathrm{d})$ & 34 & $18-51$ & 35 & $21-56$ & 25 & $15-43$ & 25 & $15-43$ \\
\hline Intake of bread (g/d) & 128 & $88-176$ & 130 & $88-170$ & 88 & $50-127$ & 89 & $51-125$ \\
\hline Intake of eggs (number/week) & 3 & $0.6-3$ & 3 & $1-3$ & 1 & $0.6-3$ & 1 & $0 \cdot 6-3$ \\
\hline
\end{tabular}

Median value was significantly different from that after 4 years of fortification $(2004-5):{ }^{\star} P=0.014,{ }^{\star \star} P=0.001,{ }^{\star \star \star} P<0.001$.

† Includes all kinds of water, soft drinks, fruit juice, coffee, tea, etc.

$\ddagger$ Includes all kinds of milk products and yogurt.

$\S$ Includes water intake and drinking milk.

years, mainly as a result of decreased fish intake and perhaps because of lower iodine content in milk $^{(26)}$.

There could be several explanations for the lower urinary iodine excretion observed in Denmark, which occurs in spite of a higher use of iodine-containing supplements. First of all, participants in the 2008-10 study were older than those in the 2004-5 study. However, urinary iodine excretion increased with age within the two studies, and the decrease in urinary iodine excretion between the studies persisted after adjustment for age, making changes in age an unlikely explanation. More participants in the 2008-10 study, which was a follow-up study, had a long education and fewer had no education compared with participants in 2004-5. High educational level has been found to be associated with higher intake of fish in a Danish study ${ }^{(27)}$. The intake of bread is probably not related to educational level ${ }^{(28)}$. A possible association of educational level with the intake of other iodine-rich food items such as milk and eggs has not been investigated, but seems unlikely due to the low cost of these foods. In a study from France, a high educational level was associated with a higher risk of having an iodine intake below $150 \mu \mathrm{g} / \mathrm{d}^{(29)}$. However, a study from Germany did not find a clear association between socio-economic status and urinary iodine excretion ${ }^{(30)}$. Although educational level could have a possible influence on urinary iodine excretion, adjustment for educational level did not change urinary iodine excretion significantly in the present study. Furthermore, the higher educational level in the 2008-10 study is expected to be associated with higher rather than lower urinary iodine excretion, and, thus, would have counteracted the decrease in urinary iodine excretion.

Table 4. lodine content in milk sampled in 2000-1 and 2013

(Mean values and standard deviations)

\begin{tabular}{|c|c|c|c|c|c|c|c|c|c|}
\hline & \multicolumn{3}{|c|}{ Dairies on Zealand } & \multicolumn{3}{|c|}{ Dairies in Jutland } & \multicolumn{3}{|c|}{ All dairies } \\
\hline & Mean & SD & $n$ & Mean & SD & $n$ & Mean & SD & $n$ \\
\hline \multicolumn{10}{|l|}{ Organic milk } \\
\hline Winter† $2000-1(\mu \mathrm{g} / 100 \mathrm{~g})$ & 12 & 2 & 5 & 10 & 3 & 10 & 10 & 3 & 15 \\
\hline Winter† $2013(\mu \mathrm{g} / 100 \mathrm{~g})$ & 14 & 2 & 5 & 13 & 4 & 21 & $13^{*}$ & 4 & 26 \\
\hline Summer $\neq 2000-1(\mu \mathrm{g} / 100 \mathrm{~g})$ & 7 & 1 & 3 & 7 & 2 & 6 & 7 & 1 & 0 \\
\hline Summer $2013(\mu \mathrm{g} / 100 \mathrm{~g})$ & 7 & 2 & 6 & 8 & 2 & 15 & 8 & 2 & 21 \\
\hline All $2000-1(\mu \mathrm{g} / 100 \mathrm{~g})$ & 10 & 3 & 8 & 8 & 3 & 16 & 9 & 3 & 24 \\
\hline All $2013(\mu \mathrm{g} / 100 \mathrm{~g})$ & 10 & 4 & 9 & 11 & 4 & 36 & $11^{\star \star}$ & 4 & 47 \\
\hline \multicolumn{10}{|l|}{ Non-organic milk } \\
\hline Winter† $2000-1(\mu \mathrm{g} / 100 \mathrm{~g})$ & 25 & 2 & 16 & 18 & 4 & 32 & 20 & 5 & 48 \\
\hline Winter† 2013 ( $\mu \mathrm{g} / 100 \mathrm{~g})$ & 13 & 1 & 12 & 13 & 2 & 10 & $13^{\star}$ & 1 & 22 \\
\hline Summer $\neq 2000-1(\mu \mathrm{g} / 100 \mathrm{~g})$ & 18 & 1 & 8 & 12 & 2 & 16 & 14 & 3 & 24 \\
\hline Summer $\neq 2013(\mu \mathrm{g} / 100 \mathrm{~g})$ & 12 & 1 & 12 & 12 & 1 & 8 & $12^{* \star *}$ & 1 & 20 \\
\hline All $2000-1(\mu \mathrm{g} / 100 \mathrm{~g})$ & 22 & 4 & 24 & 16 & 4 & 48 & 18 & 5 & 72 \\
\hline All $2013(\mu \mathrm{g} / 100 \mathrm{~g})$ & 12 & 1 & 24 & 12 & 2 & 28 & $12^{*}$ & 1 & 42 \\
\hline \multicolumn{10}{|l|}{ Overall } \\
\hline All milk $2000-1(\mu \mathrm{g} / 100 \mathrm{~g})$ & 19 & 6 & 32 & 14 & 5 & 64 & 16 & 6 & 96 \\
\hline All milk $2013(\mu \mathrm{g} / 100 \mathrm{~g})$ & 12 & 3 & 35 & 11 & 3 & 54 & $12 \S$ & 3 & 89 \\
\hline
\end{tabular}

Mean value was significantly different from that of the 2000-1 sampling: ${ }^{*} P<0.01,{ }^{* \star} P=0.037,{ }^{\star * \star} P=0.015$.

† Winter: October-April.

$\ddagger$ Summer: May-September.

$\S$ Weighted for the same distribution of organic/non-organic milk as in $2000-1$. The unweighted iodine content is $11 \mu \mathrm{g} / 100 \mathrm{~g}$. 
Dietary habits with regard to the intake of iodine-rich foods (milk, fish and bread) did not change significantly between 2004-5 and 2008-10 apart from the total fluid and water intake. This is in line with the results from the 2003-8 Danish National Survey of Dietary Habits and Physical Activity (S Fagt, unpublished results).

In Denmark, the main part of salt in the diet originates from industrial products, and the intake of household salt is approximately $1 \mathrm{~g} / \mathrm{d}^{(31)}$. The household salt and salt used in bread are iodised. An unpublished study based on the measurement of $\mathrm{Na}$ in spot urine samples found a decrease in salt intake of approximately $0.5 \mathrm{~g} / \mathrm{d}$ in women from 2006 to 2010 (U Toft, unpublished results). Thus, this small decrease in total salt intake cannot explain the decrease in iodine intake.

The salt and iodine content in bread on the Danish market has not changed from $2001-2^{(32)}$ to $2009^{(33)}$. However, the content of salt and iodine decreased non-significantly in industrially produced bread and increased significantly in breads bought in bakeries in that period (unpublished calculations based on Rasmussen et $a l^{(32)}$ and Mikkelsen et $\left.a l .{ }^{(33)}\right)$. The percentage of participants who bought bread at bakeries did not change significantly, but a higher percentage claimed to bake their own bread in the 2008-10 study. This could have influenced iodine intake slightly dependent on the amount and type of salt used for baking. In addition, $7 \%$ of the bread samples were not iodised in $2001-2^{(32)}$, whereas $13.5 \%$ of the breads sampled in $2009^{(33)}$ were not iodised. This fact can explain a minor part of the decrease in urinary iodine excretion.

We have earlier found a strong association between milk intake and urinary iodine excretion in both of the two crosssectional studies ${ }^{(6,34)}$ and in the follow-up study ${ }^{(35)}$, and even a strong association between milk intake and thyroid volume before fortification was introduced ${ }^{(36)}$. A plausible explanation for the lower urinary iodine excretion could therefore be the decreased iodine content in milk. With a median intake of 1.6 glasses of milk, corresponding to $320 \mathrm{ml}$ milk daily, the mean decrease in iodine content in milk from 16 to $12 \mu \mathrm{g} / 100 \mathrm{~g}$ would roughly account for a decrease of $13 \mu \mathrm{g}$ iodine/d, and can explain a main part of the decrease in urinary iodine excretion.

The decrease in iodine content in milk is in contrast with the results from some other countries. In Germany, an increasing trend in iodine content in milk was found from 2004 to $2010^{(8)}$, and, likewise, in Spain, iodine content has increased between 1991 and $2008^{(37)}$. Furthermore, compared with newer data from other countries, the actual measured values were relatively low; in England, the median iodine content was $14.5 \mu \mathrm{g} / 100 \mathrm{~g}$ in organic milk ( $n$ 92) and $25.0 \mu \mathrm{g} / 100 \mathrm{~g}$ in non-organic milk ${ }^{(9)}$, data from Spain showed a mean content of 25.9 (SD 5.8) $\mu \mathrm{g} / 100 \mathrm{ml}$ in $2008^{(37)}$, and in Italy, a median value of $26.4 \mu \mathrm{g} / 100 \mathrm{ml}$ was found ${ }^{(10)}$. On the other hand, data from Germany showed an iodine content of $11 \mu \mathrm{g} / 100 \mathrm{ml}^{(8)}$ and milk sampled during winter in Poland showed a content of $14.7 \mu \mathrm{g} / 100 \mathrm{ml}^{(38)}$, which is in line with the contents reported in the present study.
We did not find a difference in iodine content between skimmed milk and whole milk. This is in contrast to Soriguer et $a l^{(37)}$ who found a slight, but significantly higher content in skimmed milk than in semi-skimmed and whole milk, but is in agreement with Norwegian data ${ }^{(39)}$, data from England ${ }^{(40)}$ and older data from Finland ${ }^{(41)}$.

A limitation of the present results was that we compared a cross-sectional study (2004-5) with the results from a follow-up study (2008-10). The age groups differed between the studies, with the age being higher in the follow-up study and the participants in the follow-up study had a higher educational level than in the cross-sectional study. However, we adjusted the results for educational level and age, and these factors did not explain the decrease in urinary iodine excretion. Collection of milk samples was not part of the DanThyr studies. The milk samples presented here were sampled and analysed for iodine 3 to 4 years before the 2004-5 study and 3 to 4 years after the 2008-10 study, respectively. Thus, iodine content in milk might have been different at the time of collection of urine samples. The methods used to analyse iodine in milk were different in 2000-1 and in 2013, and this might explain a smaller part of the difference found in iodine content. However, the two iodine analysis methods gave similar results when adequately performed, and both procedures of sample preparation and subsequent analyses were tested against international iodine references ${ }^{(42)}$. Recovery of iodine during the alkaline ashing procedure was only about $95 \%$, and this loss of material can explain part of the slightly lower content found in 2013 samples compared with the samples from the 2000-1 study. An advantage of the study was that the number of participants was quite large. According to Andersen et al. ${ }^{(43)}$ a sample size of at least 400 participants is needed to get a precision range of $\pm 5 \%$ when using estimated $24 \mathrm{~h}$ iodine excretion in spot urine samples. The sample size was above this number in each sex group and in both regions. A further advantage was that the studies were carried out in exactly the same way including that the same FFQ and the same questions regarding the use of dietary supplements were asked in both studies.

In conclusion, urinary iodine excretion, expressed both as a concentration and as estimated $24 \mathrm{~h}$ iodine excretion, has decreased in women living in Denmark between 2004-5 and 2008-10. Iodine content in milk was lower in 2013 than in 2000-1, and this is probably the main explanation for the decrease in urinary iodine excretion. The median urinary iodine excretion in women is below the internationally recommended level, and it should therefore be considered to increase the general iodine intake in the Danish population slightly, for example by increasing the iodine content in salt.

\section{Acknowledgements}

The present study was supported by the Danish Medical Foundation, the North Jutland County Research Foundation, the Tømmerhandler Wilhelm Bangs Foundation, the Copenhagen Hospital Corporation Research Foundation, the Ministry of 
Food, Agriculture, and Fisheries, and the Danish Agency for Science, Technology, and Innovation.

The authors' contributions are as follows: L. O., H. P., T. J. and P. L. formulated the research questions and designed the study; A. C., L. B. and A. K. carried out the data collection; P. K. designed the data collection of the milk samples; J. J. S. carried out the analytical measurement of the milk samples from the 2000-1 study; P. L. was responsible for the milk analyses in 2013; L. B. R. analysed the data and performed the statistical analysis, wrote most of the paper and had primary responsibility for the final content. All authors read and approved the final manuscript.

There are no conflicts of interest.

\section{References}

1. Andersson M, de Benoist B \& Rogers L (2010) Epidemiology of iodine deficiency: salt iodisation and iodine status. Best Pract Res Clin Endocrinol Metab 24, 1-11.

2. Li M, Eastman J, Waite KV, et al. (2006) Are Australian children iodine deficient? Results of the Australian National Iodine Nutrition Study. MJA 184, 165-169.

3. Vanderpump MP, Lazarus JH, Smyth PP, et al. (2011) Iodine status of UK schoolgirls: a cross-sectional survey. Lancet 377, 2007-2012.

4. Johner SA, Günther ALB \& Remer T (2011) Current trends of 24-h urinary iodine excretion in German schoolchildren and the important of iodised salt in processed foods. Br J Nutr 106, 1749-1756.

5. World Health Organization (2007) Assessment of Iodine Deficiency Disorders and Monitoring their Elimination. Geneva: WHO.

6. Rasmussen LB, Carlé A, Jørgensen T, et al. (2008) Iodine intake before and after mandatory iodization in Denmark: results from the Danish Investigation of Iodine Intake and Thyroid Diseases (DanThyr) study. Br J Nutr 100, 166-173.

7. Bekendtgørelse om tilsætning af jod til husholdningssalt og salt i brød og almindeligt bagværk m.v (Departmental order regarding iodine fortification of household salt and salt used in bread etc.) Bek. Nr. 627, 29 June 2000. https://www. retsinformation.dk/Forms/R0710.aspx?id=7026 (accessed 20 July 2014).

8. Johner SA, von Nida K, Jahreis G, et al. (2012) Time trends and seasonal variation of iodine content in German cow's milk - investigations from Northrhine-Westfalia (in German). Berl Munch Tierarztl Wochenschr 125, 76-82.

9. Bath SC, Button S \& Rayman MP (2012) Iodine concentration of organic and conventional milk: implications for iodine intake. Br J Nutr 107, 935-940.

10. Watutantrige Fernando S, Barollo S, Nacamulli D, et al. (2013) Iodine status in schoolchildren living in northeast Italy: the importance of iodized-salt use and milk consumption. Eur J Clin Nutr 67, 366-370.

11. Knudsen N, Bülow I, Jørgensen T, et al. (2000) Goitre prevalence and thyroid abnormalities at ultrasonography: a comparative epidemiological study in two regions with slightly different iodine status. Clin Endocrinol 53, 479-485.

12. Vejbjerg P, Knudsen N, Perrild H, et al. (2007) Effect of a mandatory iodization program on thyroid gland volume based on individuals' age, gender, and preceding severity of dietary iodine deficiency: a prospective, populationbased study. J Clin Endocrinol Metab 92, 1397-1401.

13. Bjergved L, Jørgensen T, Perrild H, et al. (2012) Predictors of change in serum TSH after iodine fortification: an 11-year follow-up to the DanThyr study. J Clin Endocrinol Metab 97, 4022-4029.

14. Pedersen KM, Laurberg P, Nøhr S, et al. (1999) Iodine in drinking water varies by more than 100 -fold in Denmark. Importance for iodine content of infant formulas. Eur $J$ Endocrinol 140, 400-403.

15. Rasmussen LB, Ovesen L, Bülow I, et al. (2001) Evaluation of a semi-quantitative food frequency questionnaire to estimate iodine intake. Eur J Clin Nutr 55, 287-292.

16. Wilson B \& van Zyl A (1967) The estimation of iodine in thyroidal amino acids by alkaline ashing. S Afr J Med Sci 32, 70-82.

17. Laurberg P (1987) Thyroxine and 3,5,3'-triiodothyronine content of thyroglobulin in thyroid needle aspirates in hyperthyroidism and hypothyroidism. J Clin Endocrinol Metab 119, 125-131.

18. Fecher PA, Goldmann I \& Nagengast A (1998) Determination of iodine in food samples by inductively coupled plasma mass spectrometry after alkaline extraction. J Anal Atomic Spectrom 13, 977-982.

19. Toft U, Cerqueira C, Andreasen AH, et al. (2013) Estimating salt intake in a Caucasian population: can spot urine substitute 24-hour urine samples? Eur J Prev Cardiol 21, $1300-1307$.

20. Nordic Council of Ministers (2012) Nordic Nutrition Recommendations 2012. Integrating Nutrition and Physical Activity, Nord 2012: 002. Copenhagen: Nordic Council of Ministers.

21. Zimmermann MB \& Andersson M (2012) Assessment of iodine nutrition in populations: past, present, and future. Nutr Rev 70, 553-570.

22. Brantsæeter AL, Abel MH, Haugen M, et al. (2013) Risk of suboptimal iodine intake in pregnant Norwegian women. Nutrients 5, 424-440.

23. Raverot V, Bournaud C, Sassolas G, et al. (2012) Pregnant French women living in the Lyon area are iodine deficient and have elevated serum thyroglobulin concentrations. Thyroid 22, 522-528.

24. Vandevijvere S, Amsalkhir S, Mourri AB, et al. (2012) Iodine deficiency among Belgian pregnant women not fully corrected by iodine-containing multivitamins: a national cross-sectional survey. Br J Nutr 109, 2276-2284.

25. Andersen SL, Sørensen LK, Krejbjerg A, et al. (2013) Iodine deficiency in Danish pregnant women. Dan Med J 60, A4657-A4662.

26. Gunnarsdottir I, Gustavsdottir AG \& Thorsdottir I (2009) Iodine intake and status in Iceland through a period of 60 years. Food Nutr Res 27, 53.

27. Groth MV, Christensen LM, Knudsen VK, et al. (2013) Sociale forskelle. Børns kostvaner, fysiske aktivitet og overvægt \& Voksnes kostvaner (Social differences. Children's eating habits, physical activity and overweight \& Adult diets). Søborg: DTU Fødevareinstituttet. http://www.food.dtu.dk/ $\sim /$ media/Institutter/Foedevareinstituttet/Publikationer/Pub2013/Sociale_forskelle_i_kost_fysisk_aktivitet_og_overvaegt. ashx (accessed 5 July 2013).

28. Rasmussen LB, Andersen LF, Borodulin K, et al. (2012) Nordic monitoring of diet, physical activity and overweight. In First Collection of Data in All Nordic Countries 2011. Copenhagen TemaNord 2012: 552. Copenhagen: Nordic Council of Ministers.

29. Valeix P, Faure P, Péneau S, et al. (2009) Lifestyle factors related to iodine intakes in French adults. Public Health Nutr 12, 2428-2437. 
30. Völzke H, Craesmeyer C, Nauck M, et al. (2013) Association of socioeconomic status with iodine supply and thyroid disorders in Northeast Germany. Thyroid 23, 346-353.

31. Andersen L, Rasmussen LB, Larsen EH, et al. (2009) Intake of household salt in a Danish population. Eur J Clin Nutr 63, 598-604.

32. Rasmussen LB, Ovesen L, Christensen T, et al. (2007) Iodine content in bread and salt in Denmark after iodization and the influence on iodine intake. Int J Food Sci Nutr 58, 231-239.

33. Mikkelsen A/E, Rasmussen LB \& Saxholt E (2013) Jod og salt $i$ brød (Iodine and Salt in Bread). Søborg: DTU Fødevareinstituttet. http://www.food.dtu.dk/ /media/Instit utter/Foedevareinstituttet/Publikationer/Pub-2013/Rapport $\%$ 20Jod\%20og\%20salt\%20i\%20brød.ashx (accessed 8 July 2013).

34. Rasmussen LB, Ovesen L, Bülow I, et al. (2002) Dietary iodine intake and urinary iodine excretion in a Danish population: effect of geography, supplements and food choice. Br J Nutr 87, 61-69.

35. Rasmussen LB, Jørgensen T, Perrild H, et al. (2013) Mandatory iodine fortification of bread and salt increases iodine excretion in adults in Denmark - a 11-year followup study. Clin Nutr (Epublication ahead of print version 9 November 2013).

36. Rasmussen LB, Ovesen L, Bülow I, et al. (2002) Relations between various measures of iodine intake and thyroid volume, thyroid nodularity and serum thyroglobulin. Am J Clin Nutr 76, 1069-1076.

37. Soriguer F, Gutierrez-Repiso C, Gonzalez-Romero S, et al (2011) Iodine concentration in cow's milk and its relation with urinary iodine concentrations in the population. Clin Nutr 30, 44-48.

38. Brzóska F, Szybinski Z \& Sliwinski B (2009) Iodine concentration in Polish milk - variations due to season and region. Endokrynol Pol 60, 449-454.

39. Dahl L, Opsahl JA, Meltzer HM, et al. (2003) Iodine concentration in Norwegian milk and dairy products. Br J Nutr $\mathbf{9 0}$ 679-685.

40. Ministry of Agriculture Fisheries and Food (MAFF) (2000) MAFF iodine in milk food survey information sheet number 198, March 2000. http://archive.food.gov.uk/maff/archive/ food/infsheet/2000/no198/table3.htm (accessed 5 July 2013).

41. Varo P, Saari E, Passo A, et al. (1982) Iodine in Finnish foods. Int J Vitam Nutr Res 52, 80-89.

42. Kathleen L, Caldwell C, Maxwell B, et al. (2003) Use of inductively coupled plasma mass spectrometry to measure urinary iodine in NHANES 2000: comparison with previous method. Clin Chem 49, 1019-1021.

43. Andersen S, Karmisholt J, Pedersen KM, et al. (2008) Reliability of studies of iodine intake and recommendations for number of samples in groups and in individuals. $\mathrm{Br} \mathrm{J}$ Nutr 99, 813-818. 